\author{
И. А. Седакова \\ Институт славяноведения РАН \\ Москва, Россия \\ irina.a.sedakova@gmail.com
}

\title{
Нетрадиционные ценности \\ и их традиционные корреляты (2): \\ карьера, самореализация, лидерство*
}

Разделение ценностей на «традиционные» и «нетрадиционные» в данном докладе предложено не нами и даже не исследователямигуманитариями, а заявлено в общей теме для грантов на сайте европейского Фонда ERA.net в 2017 г. В рамках полученного от этого фонда гранта ученые российско-болгарско-словацкой группы пытаются провести по возможности более четкую линию между двумя обозначенными категориями, условно говоря - между ценностями «новыми» и «старыми». Разграничение, как нам кажется, может идти по нескольким параметрам [Седакова, в печати].

Первое и основное различение лежит в области формальной, т. е. собственно терминологии: слова цеенности, цуенный мы вряд ли услышим в современном значении ('важный, значимый') в экспедициях в традиционной сельской среде. Скорее, они будут соотноситься с чем-то, что имеет стоимость, материальное выражение. Это приложимо и к русскому, и к болгарскому языкам, где используется корень ц̧ен- в одном и том же значении. Рус. цзенности, болг. цзености в патриархальной культуре будут соотноситься скорее с материальной стороной и обозначать то, что имеет «стоимость» (семейное кольцо, нивы, скот) ${ }^{1}$. Таким образом, когда мы говорим о традиционных изенностях, сам термин следует считать искусственным, он не используется в подобной функции носителями культуры, а потому мы принимаем его как рабочий, сугубо в исследовательских целях. Обнаружение,

\footnotetext{
* Авторская работа выполнена по гранту РФФИ № 18-512-76003 «Лингвистическая и этнокультурная динамика традиционных и нетрадиционных ценностей в славянском мире» в рамках Программы ERA.Net.RUS Call 2018 (проект \#472-LED-SW).

1 Материально ценный объект может приобретать и духовную ценность - как родовая память, знак конфессиональной принадлежности (четки, иконы, Библия и пр.).

(С) Седакова И. А. , 2019
} 
составление списка и изучение ценностей в традиционной картине мира будут происходить через анализ слов, фольклорных и этнографических контекстов, которые высвечивают значимые, важные координаты в жизни человека.

В «новом» мире, городском и подверженном сильному западному влиянию, слово цеенности встречается именно в этом - терминологическом - значении и соотносится с определенным набором важных для индивидуума или общества понятий. Причем они артикулируются и даже декларируются: мои ценности, ценности компании, ценностные ориентиры общества и т. д.

Бросаются в глаза и другие различия между «традиционными» и «нетрадиционными» ценностями, например происхождение слов, их обозначающих. Так, «нетрадиционные» декларируемые ценности зачастую - но не всегда - являются относительно новыми заимствованиями, тогда как «традиционные» чаще всего описываются общеславянской лексикой.

Кроме того, заметны и различия в иерархии и составе «традиционных» и «нетрадиционных» ценностных понятий. Здесь же мы сделаем важную оговорку, что многие «традиционные» ценности, несмотря на динамику оценки, не отмирают: семья, труд, здоровье, красота и пр. по-прежнему входят в базовый список ценностей общества. Однако их наполнение и прагматика значительно меняются.

В докладе мы подробнее остановимся на кардинальной, очень явной, казалось бы, смене аксиологических парадигм - процессе устаревания и ухода «новых» ценностей (нередко частичного, как это было с языческой парадигмой культуры при принятии христианства, в недавнее время - с изменением социалистической идеологии ${ }^{2}$ ). Противопоставляются ли «новые» и «старые» ценности, вытесняют ли они друг друга и всегда ли актуализация новых ценностей связана с новым терминологическим аппаратом?

Представляется, что у «нетрадиционных» ценностей нередко есть «традиционное» соответствие (или пара, выражающаяся синонимом, возможно, не совсем точным). Так, например, обстоит дело с ценностными концептами «талант», «успех», «удача» [Седакова, в печати].

\footnotetext{
${ }^{2}$ См., например, о «советских» и «постперестроечных» ценностях в монографии Е. Л. Березович [2014, 423-436].
} 
Но бывают и иные случаи - термин в традиционном словаре отсутствует, а ближайшие корреляты следует искать в ассоциативном ряду, привлекая целое семантико-аксиологическое поле. Для примера в докладе мы рассмотрим современные концепты «карьера», «лидерство», «самореализация» в русском и болгарском языках. Эта лексика относительно новая, заимствованная, она не обнаруживается в аутентичном традиционном лексиконе и фольклорно-этнографическом контексте, а потому здесь надо исследовать весь комплекс значений и затем уже сравнивать аксиологическое наполнение концептов применительно к патриархальной и современной картине мира. Корреляты обнаружить можно, но различия будут весьма значительны - как в плане формы и содержания, так и в плане прагматики и аксиологического дискурса.

Березович Е. Л. Русская лексика на общеславянском фоне: семантико-мотивационная реконструкция. М., 2014.

Седакова И. А. Есть ли у нетрадиционных ценностей традиционные корреляты (1): талант, успех и удача. В печати.

DOI 10.31168/7996-2700-3.109

\section{О. В. Семенова}

Петрозаводский государственный университет

Петрозаводск, Россия semenova@454.ru

\section{Ономастикон сказок Ф. Н. Свиньина*}

Актуальность выбранной темы обусловлена нечастым обращением исследователей к изучению имен собственных, представленных в фольклорных текстах. Между тем функционирование в произведениях устного народного творчества различных индивидуализирующих артефактов, среди которых наиболее частотны имена героев и названия мест, требует особого внимания: через анализ фольклорных онимов разрешаются вопросы не только ономастические, но и этнокультурные,

\footnotetext{
* Исследование выполнено при финансовой поддержке РФФИ, проект № 18-012-00810.

(c) Семенова О. В., 2019
} 